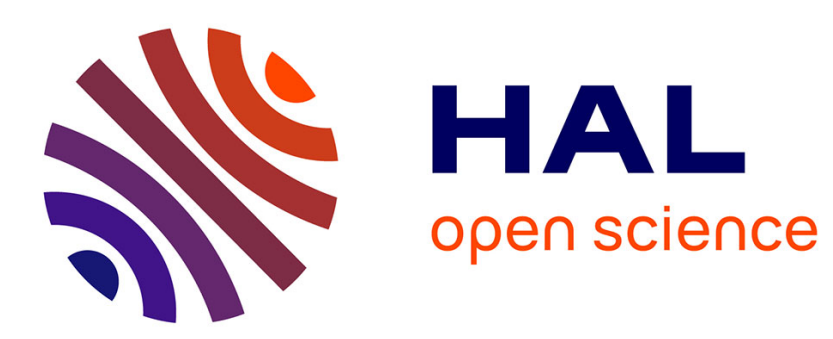

\title{
Detecting cellular damages in freezing plants: are acoustic emissions useful?
}

Guillaume Charrier, Florian Sabin, Thierry Ameglio, Christophe Serre, Stéphane Herbette, Anna Wielemans, Lia Lamacque

\section{- To cite this version:}

Guillaume Charrier, Florian Sabin, Thierry Ameglio, Christophe Serre, Stéphane Herbette, et al.. Detecting cellular damages in freezing plants: are acoustic emissions useful?. 2021 IEEE INTERNATIONAL WORKSHOP ON METROLOGY FOR AGRICULTURE AND FORESTRY, MetroAgriFor 2021, Nov 2021, Trento - Bolzano, Italy. 496 p. hal-03417274

\section{HAL Id: hal-03417274 \\ https://hal.inrae.fr/hal-03417274}

Submitted on 5 Nov 2021

HAL is a multi-disciplinary open access archive for the deposit and dissemination of scientific research documents, whether they are published or not. The documents may come from teaching and research institutions in France or abroad, or from public or private research centers.
L'archive ouverte pluridisciplinaire HAL, est destinée au dépôt et à la diffusion de documents scientifiques de niveau recherche, publiés ou non, émanant des établissements d'enseignement et de recherche français ou étrangers, des laboratoires publics ou privés. 


\section{Detecting cellular damages in freezing plants: are acoustic emissions useful?}

\author{
Guillaume Charrier \\ PIAF \\ Université Clermont \\ Auvergne, INRAE \\ Clermont-Ferrand, France \\ guillaume.charrier@inrae.fr
}

\author{
Florian Sabin \\ PIAF \\ Université Clermont \\ Auvergne, INRAE \\ Clermont-Ferrand, France \\ florian.sabin@gmail.com
}

\author{
Thierry Améglio \\ PIAF \\ Université Clermont \\ Auvergne, INRAE \\ Clermont-Ferrand, France \\ thierry.ameglio@inrae.fr \\ Christophe Serre \\ PIAF \\ Université Clermont \\ Auvergne, INRAE \\ Clermont-Ferrand, France \\ christophe.serre@inrae.fr
}

\author{
Stéphane Herbette \\ PIAF \\ Université Clermont Auvergne, \\ INRAE \\ Clermont-Ferrand, France \\ stephane.herbette@uca.fr \\ Anna Wielemans \\ PIAF \\ Université Clermont Auvergne, \\ INRAE \\ Clermont-Ferrand, France \\ anna.wielemans@gmail.com
}

\author{
Lia Lamacque \\ PIAF \\ Université Clermont \\ Auvergne, INRAE \\ Clermont-Ferrand, France \\ 1lamacque@gmail.com
}

\begin{abstract}
Ultrasonic acoustic emission analysis has often been used to detect hydraulic failures in xylem conducting elements under drought and/or frost stress. However, other sources can generate acoustic signals. In this study, we hypothesized that frost stress generates acoustic signals in living cells in relation to frost-induced dehydration. Living cells are able to transiently increase their frost resistance through the process of frost acclimation / deacclimation. The temperature at which freeze-induced acoustic signals would be recorded should therefore show seasonal changes. Well-hydrated lavender plants were frozen in three different seasons: winter (January and February), spring (April) and summer (June and July). The acoustic activity as a function of temperature showed seasonal changes. The temperature inducing $50 \%$ acoustic emissions was recorded at $-25^{\circ} \mathrm{C}$ in winter and spring while it occurred at $-15^{\circ} \mathrm{C}$ in summer. This temperature was very similar and strongly correlated to the temperature inducing $50 \%$ damages, detected by the electrolyte leakage method. Although further studies are needed to identify the exact acoustic source, these results represent a promising avenue for monitoring frost stress in a constrained environment and an alternative technique for measuring plant frost hardiness.
\end{abstract}

Keywords-Acoustic emissions, Cell lysis, Damages, Electrolyte leakage, Frost hardiness.

\section{INTRODUCTION}

Abiotic stresses (e.g. frost, drought, wind) generate significant damage to natural and cultivated plants. With the observed increase in climate variability, extreme climatic events are likely to induce more frequent and severe seasonal damage. Among them, summer drought and winter freezing events can induce critical damage at both the hydraulic (i.e. xylem embolism) and cellular levels [1]. Anticipating and mitigating these climatic risks therefore requires a precise characterization of the exposure to the different climatic stresses (intensity, frequency, type), of the spatial and temporal vulnerability to these stresses, as well as the quantification of damage in situ e.g. at the edges of species distribution [2]. Although these types of damages are physically and physiologically different, including cellular, hydraulic or mechanical failure, they share the characteristic of generating ultrasonic acoustic emissions [3]. The detection of acoustic emissions is therefore a preferred technique for monitoring damage under highly constrained environmental conditions, while being minimally invasive.

This research has been supported by the Agroecosystem INRAE department and the Auvergne-Rhône-Alpes regional Council (Pack Ambition Recherche Doux_Glace).
In different contexts, several sources of acoustic emissions have been identified during water stress and linked to cavitation events (formation of air bubbles in the sap under high tension) within the conducting tissues. Once the tension in the cell walls is released by the cavitation event, an elastic longitudinal waves propagates within a fluid medium (usually the cell walls), resulting in acoustic emission [3]. Acoustic emissions were recorded for the first time in plants in the audible range (below $20 \mathrm{kHz}$ ) during dehydration of Ricinus communis petioles [4]. These observations supported the cohesion - tension theory, suggesting the formation of cavitation events under drought conditions. Cavitation events, and the subsequent expansion of bubbles, would release local tension in the cell walls of xylem conducting elements, propagating as an acoustic wave [5].

Under drought stress, other sources than cavitation events have been suggested, such as cell wall fractures or cellular plasmolysis $[6 ; 7 ; 8]$. Furthermore, two temporally distinct stages of acoustic emissions have been recorded in dehydrating lavender plants [9]. The first stage was recorded during a rapid loss of diameter and a complete loss of hydraulic conductivity. The second one was recorded during slower diameter changes and significant increase in electrolyte leakage [10].

Under frost stress, this technique allowed the detection of ice nucleation and propagation [11]. This method can therefore be useful for locating ice in wood [12]. Once most of the water is frozen, acoustic activity resumes as the temperature continues to decrease, which is probably due to the freezing of the remaining liquid water. This second stage of acoustic emissions is correlated to frost-induced loss of hydraulic conductivity and has been suggested to be generated by the rupture of the air-water meniscii in the pit membrane, initiating the propagation of embolism [13].

In addition to the hydraulic component, acoustic activity could be generated by other sources, such as fracturing or cellular plasmolysis [6;7]. When intra-cellular sap freezes, the recording of a low temperature exotherm is synchronized with a resumption of acoustic activity [6]. Furthermore, living cells from the bark, i.e. a non-conductive tissue, generate acoustic signals during freezing [14]. It can be assumed that these acoustic signals are generated by frost-induced dehydration, which is a major factor in frost damages at the cellular level [15]. Frost resistance is dynamic and exhibits patterns of acclimation / deacclimation throughout the annual cycle [16]. In particular, the increase in solutes of the intracellular sap is 
essential to limit frost-induced dehydration and consequent damages.

In this study, we hypothesized that acoustic emissions are generated, at least partially, by cellular damage and should therefore show seasonal changes in relation to frost acclimation. Acoustic emissions patterns during controlled freeze-thaw cycles were compared to cellular damages measured by the electrolyte leakage method. These results should help to define the acoustic signatures in plants during freezing and, eventually, drying.

\section{MATERIAL AND METHODS}

\section{A. Plant material}

Twigs of well-irrigated lavender plants (Lavandula angustifolia cv Maillette) were collected at the INRAE site in Clermont-Ferrand, France $\left(45.77^{\circ} \mathrm{N} ; 3.14^{\circ} \mathrm{E}\right)$. Samples were approximately $25 \mathrm{~cm}$ long with a diameter of $c a .0 .5 \mathrm{~cm}$ and sampled at three periods: winter (January - February 2019), spring (April 2018 and April 2019) and summer (June 2018 and July 2021).

\section{B. Freezing tests}

For acoustic tests, intact branches were wrapped in Parafilm (Alcan, Montreal, QC, Canada) and exposed to one freeze-thaw cycle from $5^{\circ} \mathrm{C}$ to $-30^{\circ} \mathrm{C}$ (during the growing season) and to $-50^{\circ} \mathrm{C}$ (during winter) in a temperaturecontrolled chamber connected to a circulator bath (Ministat Huber, Offenburg, Germany. The changes in temperature were set to $5 \mathrm{~K} . \mathrm{h}^{-1}$ and the minimum temperature was held for 1 hour before thawing at the same rate.

For electrolyte leakage tests, samples were exposed to four freezing temperatures, with similar dynamic as for acoustic tests. The temperatures were set to $-15,-20,-30,-40^{\circ} \mathrm{C}$, in winter and to $-10,-15,-20,-30^{\circ} \mathrm{C}$ in spring and summer. Two additional temperature treatments were used as a negative (i.e. undamaged) and positive (i.e. fully damaged) controls at +5 and $-80^{\circ} \mathrm{C}$, respectively.

The air and xylem temperatures (below the bark) were measured by thermocouples (T-type) connected to a logger (CR1000, Campbell Scientific, UK). Three measurements were taken per minutes and averaged every minute.

\section{Acoustic measurements}

Acoustic emissions were recorded using a PCI-2 (Physical Acoustics, PAC18-bit A/D, 1 kHz-3MHz), SAMOS (1kHz$400 \mathrm{kHz}$ ) and $\mu-\mathrm{SHM}$ systems connected to acoustic sensors with a high frequency range and a flat response within this range (150-800 kHz ISD9203B) through a preamplifier set to $40 \mathrm{~dB}$. One sensor per twig was fixed directly on xylem on a debarked area $\left(\mathrm{ca} .0 .5-1 \mathrm{~cm}^{2}\right)$. The debarked area was covered with silicone grease to prevent water losses and optimize acoustic coupling before the sensor was clamped. The detection threshold was set to $42 \mathrm{~dB}$. The strength of acoustic coupling was tested using the Hsu-Nielsen method (lead break; [12] at a distance of ca. $1 \mathrm{~cm}$ from each sensor, and sensors were reinstalled when the signal amplitude was below $75 \mathrm{~dB}$. Data acquisition and preprocessing were performed using AEwin software (Mistras Holdings). Five to six plants were analyzed per period (winter, spring and summer). The PCI2 system was used in April and June 2018, the SAMOS system in February and April 2019 and the $\mu$ SHM in July 2021. The different systems are in agreement to detect acoustic activity [9].

Each acoustic wave was analyzed by the AEwin software and 7 relevant characteristics were extracted from the original signal (Amplitude, Absolute energy, Rise Angle, Duration,

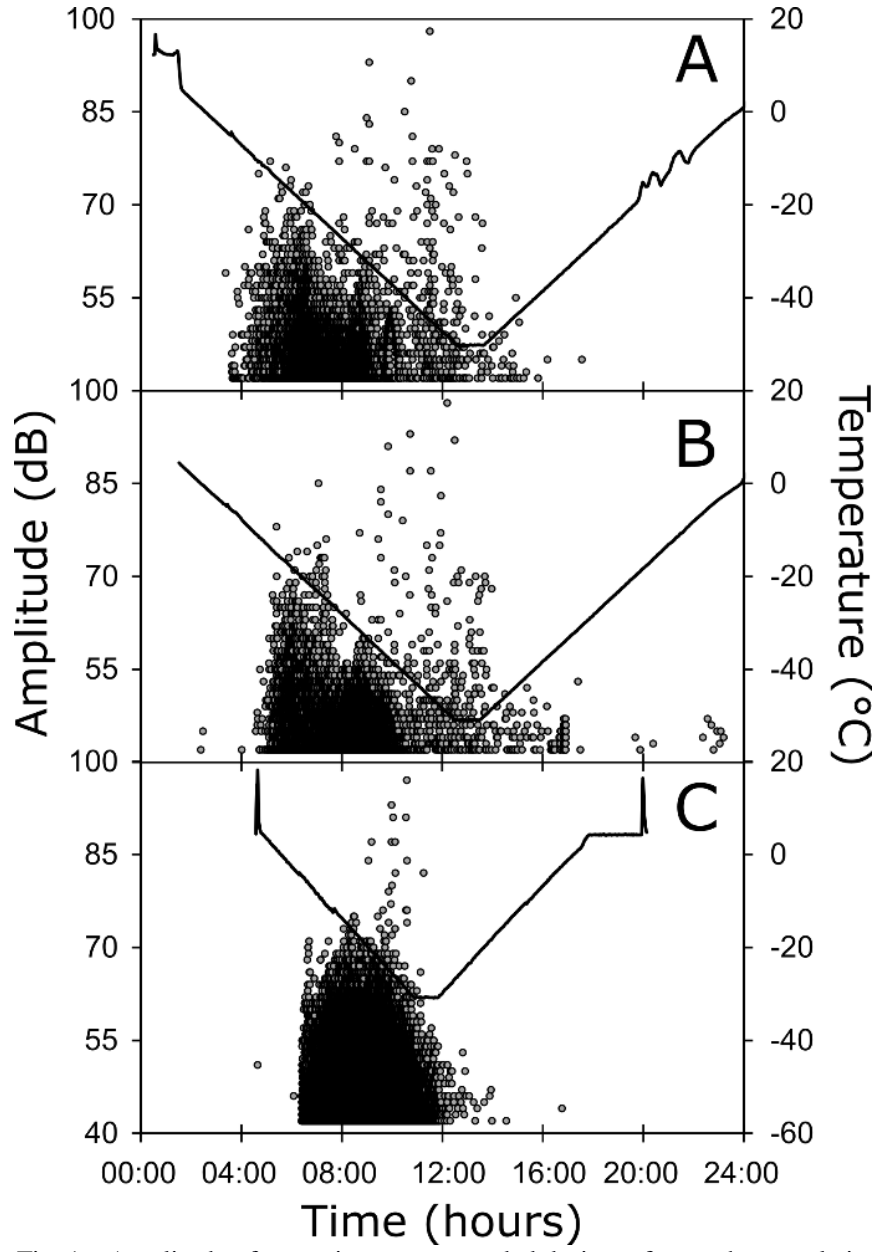

Fig. 1. Amplitude of acoustic events recorded during a freeze-thaw cycle in lavender twigs during winter (A), spring (B) and summer (C) Gray dots and black lines, respectively represent acoustic events and temperature.

Rise time, Counts to peak and Counts). The acoustic wave was also transformed using fast Fourier transform to compute 4 frequency related characteristics (Average frequency, Initiation frequency, Reverberation frequency and Weighed peak frequency).

\section{Electrolyte leakage}

Samples were cut into $5 \mathrm{~cm}$ long sections and immersed into $15 \mathrm{ml}$ of distilled-deionized water. Vials were shaken for $20 \mathrm{~h}$ at $+5{ }^{\circ} \mathrm{C}$ in the dark (to limit bacterial growth) on a horizontal gravity shaker (ST5, CAT, Staufen, Germany). The electric conductivity of the solution was measured $\left(\mathrm{C}_{1}\right)$ at room temperature using a conductimeter (Held Meter LF340, TetraCon® 325, Weiheim, Germany). After autoclaving at $+120^{\circ} \mathrm{C}$ for $30 \mathrm{~min}$ and cooling down to room temperature, the conductivity was measured again $\left(\mathrm{C}_{2}\right)$. Relative electrolyte leakage (REL) was calculated as:

$R E L=\frac{C_{1}}{C_{2}} \times 100$

To normalize the REL, unfrozen control and fully damaged samples (frozen at $-80^{\circ} \mathrm{C}$ ) were used as references for 0 (RELUnfrozen) and $100 \%$ cellular damages (REL-80), respectively. An index of frost damages (FD) was thus computed for each temperature $(\theta)$ as:

$F D=\frac{R E L_{\theta}-R E L_{U n f r o z e n}}{R E L_{-80}}$

where $\theta$ is the temperature at which sample was exposed 


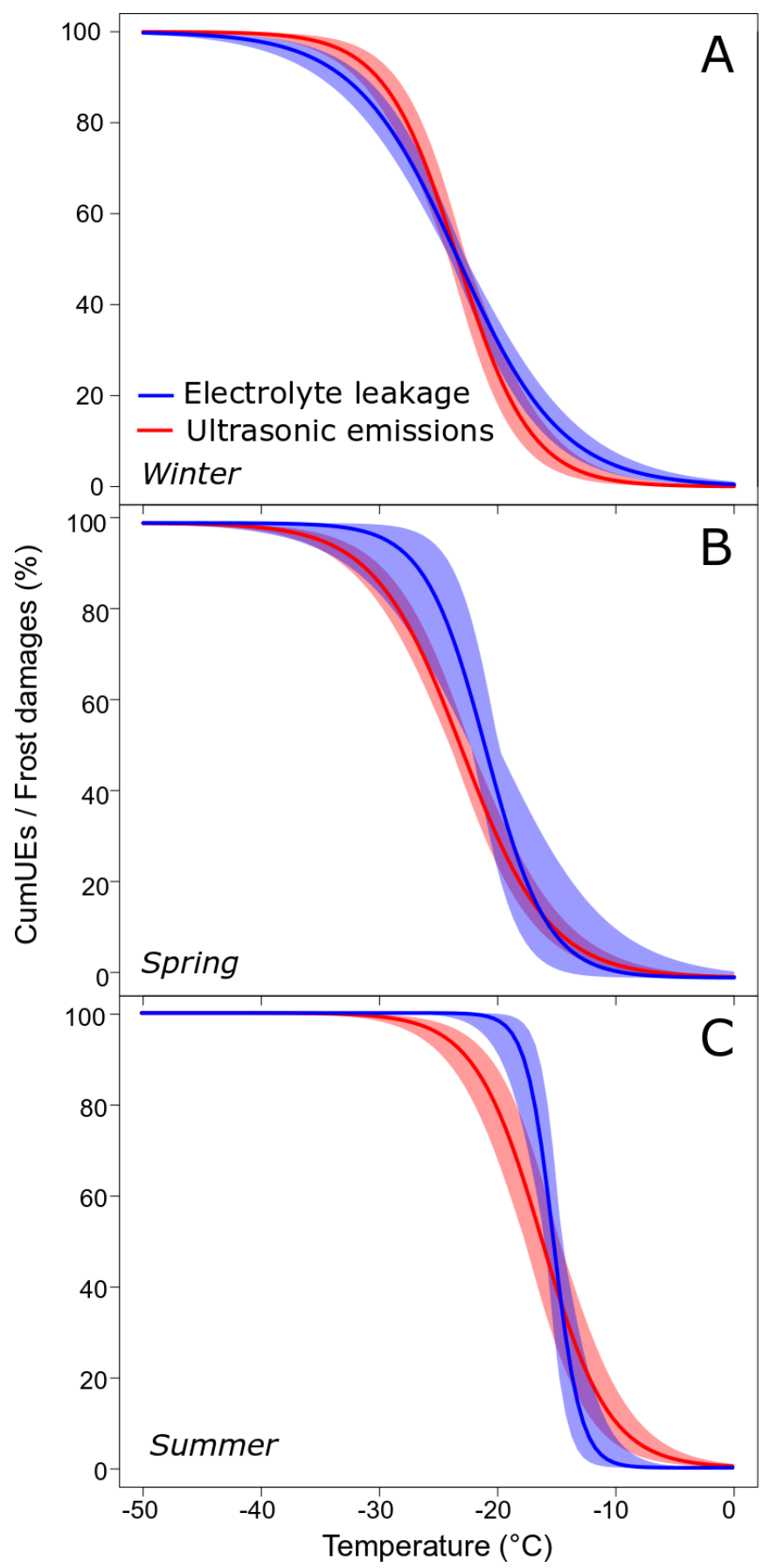

Fig. 2. Cumulated acoustic events (red line) and frost damages (blue line) depending on temperature in lavender twigs during winter (A), spring (B) and summer (C). The colored area represent the confidence interval at $95 \%$ from $\mathrm{n}=5$ to 6 replicates.

\section{E. Statistical analysis}

Statistical analyses were performed using the RStudio software (under R core version 4.0.3, R Development Core Team, 2020). The relations between cumulated ultrasonic

emissions, frost damages and temperature, were fit by minimizing Root Mean Square Error (RMSE) by using the non-linear least square nls function in $\mathrm{R}$. The following sigmoid function was used to describe the different relations:

$y=\frac{1}{1+e^{s \cdot\left(\theta-\theta_{50}\right)}}$

where $\mathrm{s}$ is the slope at the inflexion point $\theta_{50}$

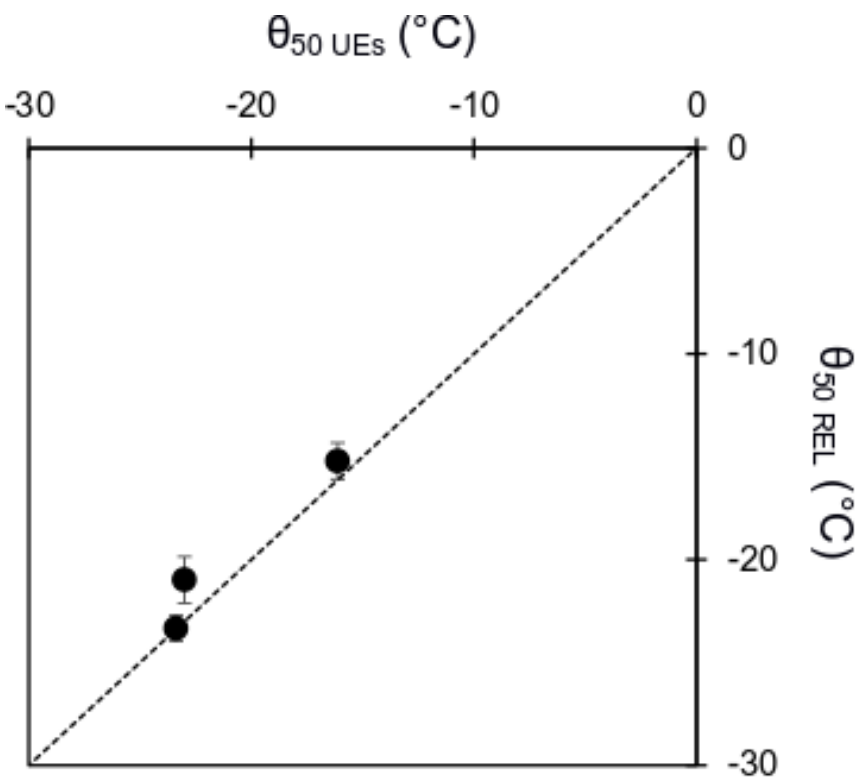

Fig. 3. Temperature inducing $50 \%$ acoustic activity ( $\theta 50$ UEs) depending on the temperature inducing $50 \%$ damages $(\theta 50 \mathrm{REL})$ in freezing lavender twigs. Symbols and bars represent the mean and standard error of $n=5-6$ replicates, respectively.

\section{RESULTS}

Acoustic emissions were only generated after plants started to freeze, as indicated by an exotherm in the sample temperature (Fig. 1). Although difficult to detect in the figure due to the thinness of the samples, the onset of freezing exotherms was consistent across seasons, occurring at approximately $-5^{\circ} \mathrm{C}$ (mean $\pm \mathrm{SE}$ : $-5.01 \pm 0.23 ;-4.90 \pm 0.26$ and $-4.99 \pm 0.18$, for winter, spring and summer periods, respectively). As the temperature decreased, acoustic activity increased until it reached ca. $-15--20^{\circ} \mathrm{C}$. At temperature below $-20^{\circ} \mathrm{C}$, additional acoustic events were recorded, although activity decreased until the minimum temperature was reached in all periods. High amplitude signals (>70 dB) were recorded during this stage. Finally, almost no acoustic emissions were recorded during the thawing stage.

A similar number of acoustic emissions were recorded in winter and spring (ca. 18,000 hits per sample), whereas twice more were recorded during summer (ca. 36, 000 hits per sample; Tab. 1). Overall, the ultrasonic events had similar amplitude, counts to peak, rise angle and initiation frequency between seasons $(46.0+/-4.6 \mathrm{~dB} ; 1.7+/-1.7 ; 30.9+/-22.9$ dB. $\mu \mathrm{s}-1 ; 755+/-477 \mathrm{kHz}$, for amplitude, counts to peak, rise angle and initiation frequency, respectively). Counts, duration and rise time were similar between winter and spring; while they were twice as large or higher in summer. Acoustic events were also of lower frequency (average frequency and weighed peak frequency). The absolute energy was relatively different across seasons, although the acoustic events recorded in summer were 10 to 20 times less energetic.

Despite these differences in the intrinsic parameters of the acoustic events, the acoustic activity closely related to temperature corresponded to a sigmoid function $(\mathrm{P}<0.001$; Fig. 2). Acoustic patterns were seasonally variable. In winter and spring, the temperature inducing $50 \%$ acoustic activity $\left(\theta_{50}\right.$ UEs) was measured at $-23.38 \pm 0.75$ and $-23.01 \pm 0.86^{\circ} \mathrm{C}$, respectively. In summer, $\theta_{50}$ UEs was observed at a higher temperature $\left(-16.13 \pm 1.46^{\circ} \mathrm{C}\right)$. The temperature inducing $50 \%$ cellular damages $\left(\theta_{50 \mathrm{REL}}\right)$ was strikingly close to $\theta_{50 \mathrm{UEs}}$, with a difference of less than $2^{\circ} \mathrm{C}$ between $\theta_{50}$ UEs and $\theta_{50 \text { REL }}$ (Fig. 3 ). Finally, in this context, cumulated acoustic emissions appear 
to be a good proxy of cellular damages, despite some outliers $\left(\mathrm{R}^{2}=0.862\right.$; Fig. 4).

\section{DISCUSSION}

Microscopic observations have demonstrated the induction of acoustic events by the nucleation of gas bubbles in the xylem conducting elements [17]. Many studies have recorded acoustic emissions to assess the level of cumulated embolism under drought stress. However, the total number of acoustic events recorded usually exceeds the total number of conducting elements in the sample [7; 18]. Furthermore, acoustic activity is recorded after the xylem is completely embolized [9], suggesting the existence of different sources. Uncertainties in the identification of acoustic sources have therefore been a strong limitation to the wide use of this technique.

During freeze-thaw cycles, ultrasonic acoustic emissions are closely related to temperature, starting as the ice nucleates and propagates, but then decreasing until the exotherm dissipates [11]. After most of the parietal water has frozen, as indicated by the dissipation of exotherm, a second stage of acoustic emissions is probably related to the displacement of air-water menisci in the punctuations of the pit membrane. This hypothesis was suggested by the significant correlation between the temperature inducing $50 \%$ of acoustic emissions during a freeze-thaw cycle and the water potential inducing 50 $\%$ loss of hydraulic conductivity [13].

Moderately dehydrated samples, at a water potential inducing $12 \%$ of loss of hydraulic conductivity, are therefore required to ensure air seeding of embolized conduits in the xylem of Picea abies [17]. In the present study, the samples were maintained at their native water potential under wellwatered conditions. Nevertheless, acoustic emissions were recorded. Previous works on acoustic emissions during freezethaw cycles has been carried out mainly on conifer wood, which is anatomically and structurally different from angiosperm wood. In contrast to the xylem of conifers, which is mainly composed of dead tracheids, the xylem of angiosperms contains a higher proportion of living cells, especially in the fibers and in the parenchyma. Seasonal change in the resistance of living cells to freezing temperature is an adaptative strategy developed by many perennial plants, called frost acclimation. Assuming that frost damage to living cells generates acoustic emissions, this may explain why, in angiosperm wood, a seasonal change in temperature inducing $50 \%$ acoustic emissions is observed, whereas this has never been reported in conifers [13].

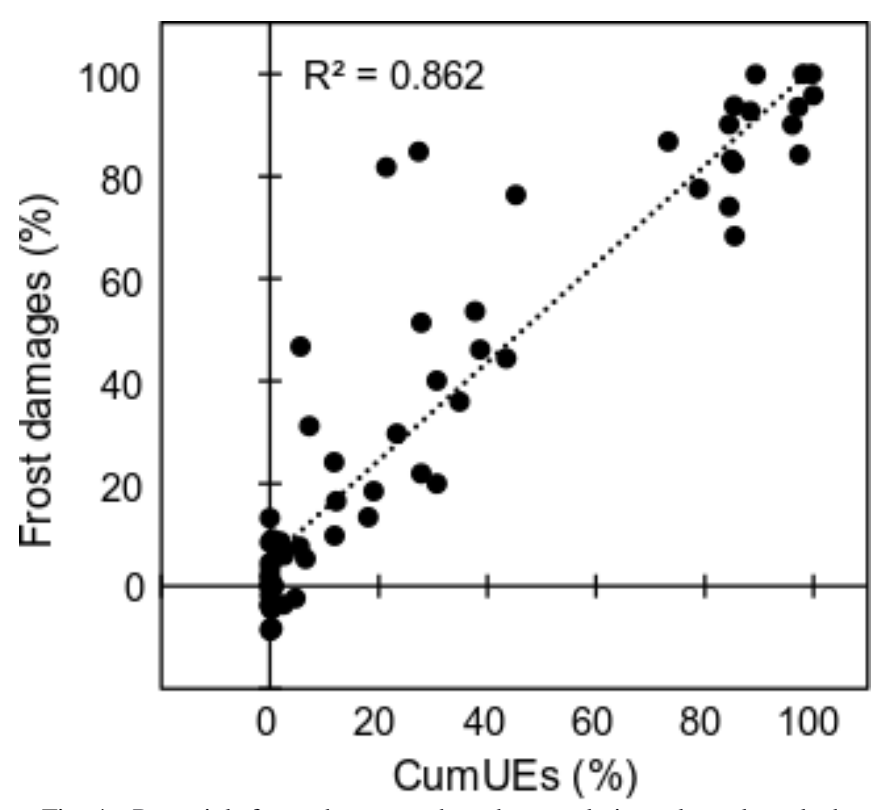

Fig. 4. Potential frost damages, based on relative electrolyte leakage, depending on cumulated ultrasonic acoustic emissions in freezing lavender twigs at different seasons.

The current study examined the seasonal trend in acoustic emissions as a function of temperature over a wide range, including periods of maximum, intermediate and minimum frost hardiness. This study therefore confirmed a seasonal dynamic in relation to the freezing resistance of living cells. The closeness of the relationship between frost damage and acoustic activity is extremely remarkable. Such a correlation supports the hypothesis that cellular damage is accompanied by the generation of acoustic emissions [10]. Although a variety of potential sources can generate signals, cellular damage is likely to account for a significant proportion (maybe more than 90\%) of the cumulated signals, which has a major influence on the overall relationship with temperature. Frostinduced dehydration induces extreme cytorrhysis of the protoplasm. Such a contraction of the protoplasm can induce high tension in the space between the cell wall and the plasma membrane, and consequently cavitation events.

The use of this technique should greatly increase the throughput of phenotyping frost resistance. Furthermore, the use of the signature of these signals should allow the definition of the acoustic signature specific to this compartment and thus discriminate the sources under different types of stress $[8 ; 10]$. This also opens up wide perspectives for the use of this technique for monitoring physiological disorders of forest and crop plants in a constrained environment.

TABLE I. DESCRIPTION OF THE MAIN PARAMETERS DETECTED DURING THE FREEZING OF LAVENDER STEMS AT THREE DIFFERENT SEASONS. N REPRESENTS THE NUMBER OF SAMPLES, $\mathrm{N}_{\mathrm{UES}}$, THE TOTAL NUMBER OF ACOUSTIC EVENTS AND THE DIFFERENT PARAMETERS (MEAN \pm SD).

\begin{tabular}{|c|c|c|c|c|c|c|c|c|c|c|c|c|c|}
\hline Season & $\mathrm{n}$ & $\mathrm{N}_{\text {UEs }}$ & Amplitude & $\begin{array}{l}\text { Absolute } \\
\text { energy }\end{array}$ & $\begin{array}{c}\text { Count } \\
s\end{array}$ & $\begin{array}{l}\text { Counts } \\
\text { to peak }\end{array}$ & Duration & $\begin{array}{l}\text { Rise } \\
\text { time }\end{array}$ & $\begin{array}{l}\text { Rise } \\
\text { angle }\end{array}$ & $\begin{array}{l}\text { Average } \\
\text { frequency }\end{array}$ & $\begin{array}{l}\text { Initiation } \\
\text { frequency }\end{array}$ & $\begin{array}{l}\text { Reverberatio } \\
\mathrm{n} \text { frequency }\end{array}$ & $\begin{array}{c}\text { Weighed } \\
\text { peak } \\
\text { frequency }\end{array}$ \\
\hline Winter & 6 & 179445 & $46.2 \pm 4.5$ & $\begin{array}{l}1987 \pm \\
250855\end{array}$ & $\begin{array}{l}3.82 \pm \\
5.12\end{array}$ & $\begin{array}{l}1.62 \pm \\
1.93\end{array}$ & & $\begin{array}{l}7.3 \pm \\
37.0\end{array}$ & $\begin{array}{c}26.6 \pm \\
15.1\end{array}$ & $469 \pm 3$ & & & $353 \pm 188$ \\
\hline Spring & 6 & 102500 & $45.7 \pm 4.8$ & $\begin{array}{c}4696 \pm \\
392000\end{array}$ & $\begin{array}{l}3.20 \pm \\
4.49\end{array}$ & $\begin{array}{l}1.46 \pm \\
1.33\end{array}$ & & $\begin{array}{l}5.0 \pm \\
23.8\end{array}$ & $\begin{array}{l}33.4 \pm \\
24.2\end{array}$ & & $754 \pm 449$ & $126 \pm 206$ & $358 \pm 209$ \\
\hline Summer & 5 & 116022 & $46.0 \pm 4.5$ & $\begin{array}{l}244 \pm \\
43255\end{array}$ & $\begin{array}{l}6.87 \pm \\
5.09\end{array}$ & $\begin{array}{l}1.98 \pm \\
1.72\end{array}$ & $\begin{array}{l}69.8 \pm \\
172.6\end{array}$ & $\begin{array}{l}27.3 \pm \\
117.7\end{array}$ & $\begin{array}{l}35.5 \pm \\
29.5\end{array}$ & $325 \pm 177$ & $765 \pm 335$ & $247 \pm 171$ & $311 \pm 120$ \\
\hline All & 17 & 397967 & $46.0 \pm 4.6$ & $\begin{array}{l}2176 \pm \\
261725\end{array}$ & $\begin{array}{l}4.55 \pm \\
5.18\end{array}$ & $\begin{array}{c}1.68 \pm \\
1.74\end{array}$ & $\begin{array}{l}36.5 \pm \\
112.8\end{array}$ & $\begin{array}{c}12.5 \pm \\
69.9\end{array}$ & $\begin{array}{c}30.9 \pm \\
22.9\end{array}$ & $425 \pm$ & $755 \pm$ & $187 \pm 215$ & $342 \pm 178$ \\
\hline
\end{tabular}




\section{REFERENCES}

[1] Charra-Vaskou, K., Charrier, G., Wortemann, R., Beikircher, B., Cochard, H., Ameglio, T., \& Mayr, S. (2012). Drought and frost resistance of trees: a comparison of four species at different sites and altitudes. Annals of Forest Science, 69(3), 325-333.

[2] Charrier, G., Nolf, M., Leitinger, G., Charra-Vaskou, K., Losso, A., Tappeiner, U., ... \& Mayr, S. (2017). Monitoring of freezing dynamics in trees: a simple phase shift causes complexity. Plant Physiology, 173(4), 2196-2207.

[3] De Roo, L., Vergeynst, L. L., De Baerdemaeker, N. J., \& Steppe, K. (2016). Acoustic emissions to measure drought-induced cavitation in plants. Applied Sciences, 6(3), 71.

[4] Milburn, J. A., \& Johnson, R. P. C. (1966). The conduction of sap. Planta, 69(1), 43-52.

[5] Jackson, G. E., \& Grace, J. (1996). Field measurements of xylem cavitation: are acoustic emissions useful?. Journal of Experimental Botany, 47(11), 1643-1650.

[6] Kasuga, J., Charrier, G., Uemura, M., \& Améglio, T. (2015). Characteristics of ultrasonic acoustic emissions from walnut branches during freeze-thaw-induced embolism formation. Journal of experimental botany, 66(7), 1965-1975.

[7] Vergeynst, L. L., Sause, M. G., Hamstad, M. A., \& Steppe, K. (2015). Deciphering acoustic emission signals in drought stressed branches: the missing link between source and sensor. Frontiers in plant science, $6,494$.

[8] Wolkerstorfer, S. V., Rosner, S., \& Hietz, P. (2012). An improved method and data analysis for ultrasound acoustic emissions and xylem vulnerability in conifer wood. Physiologia Plantarum, 146(2), 184191.

[9] Lamacque, L., Sabin, F., Améglio, T., Herbette, S., \& Charrier, G. (2021). Detection of acoustic events in Lavender for measuring the xylem vulnerability to embolism and cellular damages. arXiv preprint arXiv:2105.03866

[10] Lamacque, L., Charrier, G., Farnese, F. D. S., Lemaire, B., Améglio, T., \& Herbette, S. (2020). Drought-induced mortality: Branch diameter variation reveals a point of no recovery in lavender species. Plant physiology, 183(4), 1638-1649.

[11] Charrier, G., Pramsohler, M., Charra - Vaskou, K., Saudreau, M., Améglio, T., Neuner, G., \& Mayr, S. (2015). Ultrasonic emissions during ice nucleation and propagation in plant xylem. New Phytologist, 207(3), 570-578.

[12] Charrier, G., Charra-Vaskou, K., Legros, B., Améglio, T., \& Mayr, S. (2014). Changes in ultrasound velocity and attenuation indicate freezing of xylem sap. Agricultural and Forest Meteorology, 185, 2025.

[13] Charrier, G., Charra-Vaskou, K., Kasuga, J., Cochard, H., Mayr, S., \& Améglio, T. (2014). Freeze-thaw stress: effects of temperature on hydraulic conductivity and ultrasonic activity in ten woody angiosperms. Plant Physiology, 164(2), 992-998.

[14] Kikuta, S. B. (2003). Ultrasound acoustic emissions from bark samples differing in anatomical characteristics. Phyton, 43(1), 161-178.

[15] Arora, R. (2018). Mechanism of freeze-thaw injury and recovery: a cool retrospective and warming up to new ideas. Plant Science, 270, 301-313.

[16] Charrier, G., Poirier, M., Bonhomme, M., Lacointe, A., \& Améglio, T. (2013). Frost hardiness in walnut trees (Juglans regia L.): How to link physiology and modelling?. Tree Physiology, 33(11), 1229-1241.

[17] Ponomarenko, A., Vincent, O., Pietriga, A., Cochard, H., Badel, É., \& Marmottant, P. (2014). Ultrasonic emissions reveal individual cavitation bubbles in water-stressed wood. Journal of the Royal Society Interface, 11(99), 20140480.

[18] Rosner, S., Klein, A., Wimmer, R., \& Karlsson, B. (2006). Extraction of features from ultrasound acoustic emissions: a tool to assess the hydraulic vulnerability of Norway spruce trunkwood?. New Phytologist, 171(1), 105-116.

[19] Mayr, S., Cochard, H., Améglio, T., \& Kikuta, S. B. (2007). Embolism formation during freezing in the wood of Picea abies. Plant physiology, 143(1), 60-67. 